Review began 11/25/2021 Review ended 11/28/2021 Published 11/30/2021

(c) Copyright 2021

Ali et al. This is an open access article distributed under the terms of the Creative Commons Attribution License CC-BY 4.0. which permits unrestricted use, distribution, and reproduction in any medium, provided the original author and source are credited.

\section{A Rare Case of Mesalazine-Induced Acute Myocarditis in a 19-Year-Old Female With Ulcerative Colitis}

Abuobeida Ali ${ }^{1}$, Aravind Sunderavel Kumaravel Kanagavelu ${ }^{2}$, Abdulhameed Rahimi ${ }^{1}$, Zia Mehmood ${ }^{3}$, Adeel B. Tariq ${ }^{1}$, Tapas Das ${ }^{1}$, Ali Elmdaah ${ }^{1}$

1. Gastroenterology, Peterborough City Hospital, Peterborough, GBR 2. Internal Medicine, Peterborough City Hospital, Peterborough, GBR 3. Cardiology, Peterborough City Hospital, Peterborough, GBR

Corresponding author: Abuobeida Ali , abuobeida.elhajali@nhs.net

\begin{abstract}
Mesalazine is a commonly used first-line therapy to treat acute mild to moderate ulcerative colitis (UC). Myocarditis is a rare complication of inflammatory bowel disease. This is a case report of a 19-year-old female with myocarditis induced after commencing mesalazine for UC. She was admitted with pleuritic-type chest pain associated with severe dyspnoea and was hemodynamically unstable during admission. She had elevated troponin and N-terminal pro-B-type natriuretic peptide. Transthoracic echocardiogram (TTE) results suggested there was evidence of myocarditis with reduced ejection fraction, which was later confirmed by cardiac magnetic resonance imaging. There was a rapid improvement of cardiac status after stopping mesalazine within two weeks.
\end{abstract}

Categories: Cardiology, Internal Medicine, Gastroenterology

Keywords: cardiac magnetic resonance imaging, inflammatory bowel disease, cardiac mri, myocarditis, mesalazine, ulcerative colitis

\section{Introduction}

Inflammatory bowel disease (IBD) is a disorder causing chronic inflammation of the gastrointestinal tract. IBD types include ulcerative colitis (UC) and Crohn's disease (CD). Mucosal healing (Mayo endoscopic scores (MES) 0) remains the mainstay of treatment for IBD. Mesalazine is a commonly used first-line therapy to treat acute attacks of mild to moderate ulcerative colitis (UC) and maintenance of remission [1].

Myocarditis is a rare complication of IBD with an incidence of $0.3 \%$ [2]. But mesalazine-induced myocarditis is an even rarer but recognized complication and may develop potentially to cause cardiogenic shock and death [3]. We present a case of a 19-year-old female with myocarditis induced after starting mesalazine for UC and conduct a review of the literature.

\section{Case Presentation}

A 19-year-old, otherwise fit-and-well female presented to our hospital with an acute flare-up of UC with bloody diarrhea for a few days. She was a non-smoker and non-alcoholic. Based on the results of flexible sigmoidoscopy and biopsy, the diagnosis of moderate UC was established and a maximum dose of oral mesalazine 2.4 grams a day and a tapering dose of oral prednisolone (starting at $30 \mathrm{mg}$ OD) were prescribed. She responded well to treatment, reporting improved abdominal symptoms.

However, four weeks later, she was readmitted with a central, sharp, pleuritic-type chest pain associated with severe dyspnoea without any prodromal symptoms like fever, myalgia, or cough. On initial assessment in the emergency department, she was dyspnoeic, tachycardic with a blood pressure of $80 / 60 \mathrm{mmHg}$ and oxygen saturation of $80 \%$ requiring 10 liters of oxygen to be maintained above $94 \%$. The patient's cardiovascular and respiratory examinations were unremarkable.

Her resting 12-lead electrocardiogram (ECG) revealed sinus tachycardia without any ST changes. There was an elevated cardiac troponin-T enzyme of $64 \mathrm{ng} / \mathrm{ml}$ (laboratory normal of $<5 \mathrm{ng} / \mathrm{mL}$ ) and normal serum electrolytes. Based on this, she was treated for acute coronary syndrome with dual antiplatelet therapy and was admitted to the coronary care unit (CCU). Meanwhile, she was also investigated to rule out pulmonary embolism. D-dimer was negative, and computed tomography of pulmonary angiogram was unremarkable.

In the next few days, our patient further developed features of heart failure and cardiogenic shock for which she was treated with inotropes and furosemide infusion to offload. N-terminal pro-B-type natriuretic peptide (NT-Pro BNP) came back as $>34,000 \mathrm{pg} / \mathrm{mL}$ (laboratory normal of $<300 \mathrm{pg} / \mathrm{mL}$ ), and chest X-ray confirmed the evidence of pulmonary edema. Transthoracic echocardiogram (TTE) results suggested that there is evidence of dilated cardiomyopathy and myocarditis with severely impaired left ventricular systolic 


\section{Cureus}

function and ejection fraction (LVEF) of 31\%. Following this, cardiac magnetic resonance imaging (CMR) was performed, which confirmed myocarditis. The viral, autoimmune, metabolic, and vasculitic screens came back negative.

Based on the above investigations, the diagnosis of acute myocarditis was made after excluding other aetiologies. Subsequently, mesalazine was stopped immediately and analgesics were prescribed to alleviate pain. She was then referred to the gastroenterology team regarding further advice on managing ulcerative colitis for which they suggested biologic therapy with "infliximab" as per local trust guidelines. The rapid improvement in the patient's cardiac status after drug discontinuation supported the diagnosis of myocarditis induced by mesalazine.

Repeat TTE in two weeks' time showed an improvement in left ventricular ejection fraction (LVEF) of $48 \%$. The two-month follow-up TTE showed complete recovery with a 59\% LVEF with normal biventricular size and function (Table 1). There was reduced gadolinium enhancement of the epicardium and myocardium in the follow-up CMR confirming recovery. Recent TTE done two years later showed LVEF of $61 \%$ confirming there is no residual myocarditis (Table 1).

\begin{tabular}{|l|l|l|l|}
\hline & At the time of presentation & $\mathbf{2}$ months after stopping mesalazine & 1 year after stopping mesalazine \\
\hline LVEF $\%$ & $31 \%$ & $59 \%$ & $61 \%$ \\
\hline Troponin $\mathrm{ng} / \mathrm{L}$ & 63 & $<5$ & $<5$ \\
\hline NT-Pro BNP pg/mL & $>34,000$ & 871 & $<300$ \\
\hline
\end{tabular}

\section{TABLE 1: Timeline and cardiac investigations}

LVEF: left ventricular ejection fraction; NT-Pro BNP: N-terminal pro-b-type natriuretic peptide

\section{Discussion}

Mesalazine is a form of aminosalicylate (5-ASA) that does not contain a sulfa group. Mesalazine (5-ASA) is a commonly used IBD drug because of its anti-inflammatory action on colonic epithelial cells [4]. Though this mechanism is still unclear, research shows that mesalazine produces its effects by inhibiting proinflammatory mediators like Roms, Leukotrienes, Interleukin 1, and Tumour Necrosis Factor-alpha (TNF $\alpha$ ) [4]. Like any drug, mesalazine also has side effects but myocarditis is one of the rare or very rare complications of mesalazine [3].

Myocarditis simply means the inflammation of the heart muscles. In the acute type of myocarditis, patients usually present with chest pain, dyspnoea, or palpitations [5]. These symptoms are common for most cardiovascular symptoms and hence further investigation is necessary to exclude other causes. Laboratory investigations show raised troponin levels. ECG might reveal non-specific changes like sinus tachycardia, ST-wave, and T-wave abnormalities. Echocardiograms might show new wall motion abnormalities. Among the non-invasive investigations, cardiac MRI is ideal for confirming the diagnosis [5-6]. The criteria for suspecting myocarditis includes cardiovascular symptoms alone with either raised cardiac enzymes or ECG changes or abnormal imaging (echo or cardiac MRI). However, immunohistology remains the gold-standard investigation for diagnosing acute myocarditis.

The common causes of myocarditis include bacterial (like Staphylococcus, Streptococcus, etc.), viral (Coxsackieviruses, adenoviruses, etc.), fungal (Aspergillus, Actinomyces, etc.), and parasitic (Trichinella, Echinococcus, etc.) infections. Chemicals, drug therapies, and autoimmune diseases can also cause acute myocarditis. But it is also well-established that patients with inflammatory bowel diseases are at a higher risk of developing myopericarditis [5,7]. But there is no particular symptom, investigations, imaging studies, or immune-histological evidence that are unique to mesalazine-induced myocarditis and differentiate it from the others.

Based on an extensive literature search, we can note that the onset of symptoms from starting mesalazine has mostly been around two to four weeks time, which was similar to our patient's presentation. As per our literature review, all nine patients had a raised troponin level, which was again similar to our case. Most cases either showed sinus tachycardia or nonspecific ST changes. The majority of the cases from our literature documents showed myocarditis changes with reduced ejection fraction, in some cases up to $25 \%$ on TTE and CMR (Table 2). 


\section{Cureus}

\begin{tabular}{|c|c|c|c|c|c|c|c|c|}
\hline $\begin{array}{l}\text { Author } \\
\text { (Reference) }\end{array}$ & $\begin{array}{l}\text { Age, } \\
\text { gender }\end{array}$ & $\begin{array}{l}\text { inflammatory } \\
\text { bowel } \\
\text { disease }\end{array}$ & $\begin{array}{l}\text { mesalazine } \\
\text { given }\end{array}$ & Troponin & $\begin{array}{l}\text { 12-lead } \\
\text { electrocardiogram }\end{array}$ & $\begin{array}{l}\text { echocardiogram } \\
\text { (Ejection } \\
\text { fraction) }\end{array}$ & $\begin{array}{l}\text { magnetic } \\
\text { resonance } \\
\text { imaging }\end{array}$ & $\begin{array}{l}\text { Treatment \& } \\
\text { Outcome }\end{array}$ \\
\hline $\begin{array}{l}\text { Carlos Galvao } \\
\text { Braga [8] }\end{array}$ & $\begin{array}{l}19 \\
\text { years, } \\
\text { male }\end{array}$ & $\begin{array}{l}\text { Crohn's } \\
\text { disease }\end{array}$ & 2 weeks & $\begin{array}{l}\text { Peak } \\
\text { troponin } \\
\text { l: } 27.3 \\
\mathrm{ng} / \mathrm{ml}\end{array}$ & $\begin{array}{l}\text { Slight ST-segment } \\
\text { elevation with an } \\
\text { upward concavity } \\
\text { in leads I, II, III, } \\
\text { aVF, and V3-V6. }\end{array}$ & $\begin{array}{l}\text { Global } \\
\text { hypocontractility } \\
\text { (EF: } 38 \%)\end{array}$ & $\begin{array}{l}\text { Multiple areas } \\
\text { of myocardial } \\
\text { fibrosis, } \\
\text { mainly sub- } \\
\text { epicardium. }\end{array}$ & $\begin{array}{l}\text { Cessation of } \\
\text { mesalazine \& } \\
\text { improved well in } \\
\text { one week. }\end{array}$ \\
\hline Amira Ibrahim [9] & $\begin{array}{l}21 \\
\text { years, } \\
\text { male }\end{array}$ & $\begin{array}{l}\text { Crohn's } \\
\text { disease }\end{array}$ & 4 weeks & $\begin{array}{l}\text { Troponin } \\
\mathrm{I}: 2.21 \\
\mathrm{ng} / \mathrm{ml}\end{array}$ & $\begin{array}{l}\text { First-degree heart } \\
\text { block and non- } \\
\text { specific ST-T } \\
\text { changes. }\end{array}$ & $\begin{array}{l}\text { Normal wall } \\
\text { motion (EF: 55- } \\
60 \% \text { ) }\end{array}$ & $\begin{array}{l}\text { Subepicardial } \\
\text { to mid- } \\
\text { myocardial } \\
\text { delayed } \\
\text { gadolinium } \\
\text { hyper- } \\
\text { enhancement } \\
\text { and edema } \\
\text { involving the } \\
\text { basal inferior } \\
\text { to the } \\
\text { inferolateral } \\
\text { wall. }\end{array}$ & $\begin{array}{l}\text { Cessation of } \\
\text { mesalazine \& } \\
\text { marked } \\
\text { improvement in } 48 \\
\text { hours. }\end{array}$ \\
\hline $\begin{array}{l}\text { William L } \\
\text { Baker [10] }\end{array}$ & $\begin{array}{l}38 \\
\text { years, } \\
\text { male }\end{array}$ & $\begin{array}{l}\text { Crohn's } \\
\text { disease }\end{array}$ & 3 weeks & $\begin{array}{l}\text { Troponin } \\
\text { I: } 3.37 \\
\mathrm{ng} / \mathrm{ml}\end{array}$ & $\begin{array}{l}\text { Sinus tachycardia } \\
\text { with T-wave } \\
\text { flattening. }\end{array}$ & $\begin{array}{l}\text { Mildly impaired } \\
\text { left ventricular } \\
\text { systolic function } \\
\text { and inferolateral } \\
\text { wall hypokinesia } \\
\text { (EF:40\%) }\end{array}$ & $\begin{array}{l}\text { Mild global } \\
\text { hypokinesis of } \\
\text { the left } \\
\text { ventricle, and } \\
\text { patchy mid- } \\
\text { myocardial } \\
\text { late } \\
\text { gadolinium } \\
\text { enhancement } \\
\text { in the } \\
\text { posterior wall } \\
\text { of the left } \\
\text { ventricle and, } \\
\text { to a lesser } \\
\text { degree, in the } \\
\text { inferior } \\
\text { interventricular } \\
\text { septum. }\end{array}$ & $\begin{array}{l}\text { Cessation of } \\
\text { mesalazine, } \\
\text { metoprolol } \\
\text { succinate \& } \\
\text { resolution of } \\
\text { symptoms in } 4 \\
\text { days. }\end{array}$ \\
\hline $\begin{array}{l}\text { Kelechukwu U. } \\
\text { Okoro [11] }\end{array}$ & $\begin{array}{l}23 \\
\text { years, } \\
\text { male }\end{array}$ & $\begin{array}{l}\text { Ulcerative } \\
\text { colitis }\end{array}$ & 6 months & $\begin{array}{l}\text { Troponin } \\
14.55 \\
\text { ng/dl }\end{array}$ & $\begin{array}{l}\text { Sinus tachycardia } \\
\text { without ischaemic } \\
\text { changes. }\end{array}$ & $\begin{array}{l}\text { Akinetic apex } \\
\text { (EF: Preserved) }\end{array}$ & $\begin{array}{l}\text { Linear } \\
\text { delayed hyper- } \\
\text { enhancement } \\
\text { involving the } \\
\text { mid- } \\
\text { myocardium of } \\
\text { the distal } \\
\text { septum. }\end{array}$ & $\begin{array}{l}\text { Cessation of } \\
\text { mesalazine, } \\
\text { methylprednisolone } \\
\text { started \& the } \\
\text { condition improved. }\end{array}$ \\
\hline $\begin{array}{l}\text { Mohamed E. } \\
\text { Taha [12] }\end{array}$ & $\begin{array}{l}18 \\
\text { years, } \\
\text { female }\end{array}$ & $\begin{array}{l}\text { Ulcerative } \\
\text { colitis }\end{array}$ & 2 weeks & $\begin{array}{l}\text { Peak } \\
\text { troponin I } \\
5.59 \mu \mathrm{g} / \mathrm{L}\end{array}$ & $\begin{array}{l}\text { Sinus tachycardia, } \\
\text { borderline T-wave } \\
\text { abnormalities in } \\
\text { leads II, III and AVF }\end{array}$ & $\begin{array}{l}\text { Normal left } \\
\text { ventricular size, } \\
\text { thickness, } \\
\text { systolic and } \\
\text { diastolic function. } \\
\text { (EF:55\%) }\end{array}$ & $\begin{array}{l}\text { Delayed } \\
\text { enhancement } \\
\text { showed trace } \\
\text { pericardial } \\
\text { effusion. }\end{array}$ & $\begin{array}{l}\text { Cessation of } \\
\text { mesalazine \& } \\
\text { symptoms resolved } \\
\text { in } 48 \text { hours. }\end{array}$ \\
\hline $\begin{array}{l}\text { Shiva T. } \\
\text { Radhakrishnan [13] }\end{array}$ & $\begin{array}{l}49 \\
\text { years, }\end{array}$ & $\begin{array}{l}\text { Ulcerative } \\
\text { colitis }\end{array}$ & 2 weeks & $\begin{array}{l}\text { Troponin } \\
\text { T } 146\end{array}$ & Sinus tachycardia & $\begin{array}{l}\text { Not mentioned in } \\
\text { the article. }\end{array}$ & $\begin{array}{l}\text { Subepicardial } \\
\text { delayed } \\
\text { gadolinium } \\
\text { enhancement } \\
\text { in the basal to } \\
\text { middle inferior } \\
\text { and } \\
\text { inferolateral } \\
\text { segments of }\end{array}$ & $\begin{array}{l}\text { Cessation of } \\
\text { mesalazine \& } \\
\text { improvement in }\end{array}$ \\
\hline
\end{tabular}




\section{Cureus}

\begin{tabular}{|c|c|c|c|c|c|c|c|c|}
\hline & male & & & $\mathrm{ng} / \mathrm{ml}$ & & & $\begin{array}{l}\text { the heart with } \\
\text { matching high } \\
\text { signal intensity } \\
\text { seen on T2- } \\
\text { weighted } \\
\text { images of the } \\
\text { same area. }\end{array}$ & $\begin{array}{l}\text { patient's condition } \\
\text { in } 3 \text { days. }\end{array}$ \\
\hline $\begin{array}{l}\text { Michele } \\
\text { Sorleto [14] }\end{array}$ & $\begin{array}{l}18 \\
\text { year, } \\
\text { male }\end{array}$ & $\begin{array}{l}\text { Crohn's } \\
\text { disease }\end{array}$ & 6 months & $\begin{array}{l}\text { Troponin } \\
\text { hs:1158 } \\
\text { pg/ml }\end{array}$ & $\begin{array}{l}\text { ST-segment } \\
\text { elevation with an } \\
\text { upward concavity } \\
\text { in leads II, III, aVF, } \\
\text { and V4-V6 }\end{array}$ & $\begin{array}{l}\text { Not mentioned in } \\
\text { the article. }\end{array}$ & $\begin{array}{l}\text { Late } \\
\text { gadolinium } \\
\text { enhancement } \\
\text { and } \\
\text { myopericardial } \\
\text { edema. }\end{array}$ & $\begin{array}{l}\text { Cessation of } \\
\text { mesalazine and } \\
\text { symptoms } \\
\text { normalized within } 7 \\
\text { days. }\end{array}$ \\
\hline $\begin{array}{l}\text { Thomas } \\
\text { Kingston [15] }\end{array}$ & $\begin{array}{l}23 \\
\text { years, } \\
\text { male }\end{array}$ & $\begin{array}{l}\text { Ulcerative } \\
\text { colitis }\end{array}$ & 5 months & $\begin{array}{l}\text { Troponin } \\
14.5 \\
\mathrm{ng} / \mathrm{ml}\end{array}$ & $\begin{array}{l}\text { Not mentioned in } \\
\text { the article. }\end{array}$ & Akinetic apex. & $\begin{array}{l}\text { Linear } \\
\text { delayed hyper- } \\
\text { enhancement } \\
\text { involving the } \\
\text { mid- } \\
\text { myocardium of } \\
\text { the distal } \\
\text { septum. }\end{array}$ & $\begin{array}{l}\text { Cessation of } \\
\text { mesalazine, } \\
\text { commencement of } \\
\text { IV steroids \& } \\
\text { prompt resolution } \\
\text { of symptoms }\end{array}$ \\
\hline Thomas Mellor [16] & $\begin{array}{l}27 \\
\text { years, } \\
\text { male }\end{array}$ & $\begin{array}{l}\text { Crohn's } \\
\text { disease }\end{array}$ & 3 weeks & $\begin{array}{l}\text { Troponin } \\
\text { I: } 0.92 \\
\text { ng/ml }\end{array}$ & $\begin{array}{l}\text { No ischaemic } \\
\text { changes. }\end{array}$ & $\begin{array}{l}\text { Biventricular } \\
\text { dilation, (EF:25- } \\
30 \%)\end{array}$ & $\begin{array}{l}\text { Late } \\
\text { enhancement } \\
\text { of the } \\
\text { subepicardial } \\
\text { lateral wall. }\end{array}$ & $\begin{array}{l}\text { Cessation of } \\
\text { mesalazine \& } \\
\text { improvement of } \\
\text { symptoms. }\end{array}$ \\
\hline
\end{tabular}

\section{TABLE 2: A summary of case studies about mesalazine-induced myocarditis}

The definitive treatment of mesalazine-induced myocarditis has been the abrupt cessation of the drug. In most patients, it yielded a rapid resolution of symptoms without any chronic residual changes. In a few patients, short courses of steroids have been used although it's still not clear and indicated. Our patient improved drastically after discontinuing medication without the use of steroids. Her follow-up scan in three years' time reassured that there were no chronic changes because of the toxicity (Table 2).

\section{Conclusions}

This patient's case illustrates that clinicians should be more alert and aware of this very rare but potentially life-threatening adverse effect of mesalazine because this drug is widely prescribed for patients with IBD. It is essential to consider myocarditis as an important differential diagnosis of chest pain in a patient taking mesalazine because the primary management simply involves discontinuing the medication. This would improve the disease quite rapidly without causing permanent after-effects.

\section{Additional Information}

\section{Disclosures}

Human subjects: Consent was obtained or waived by all participants in this study. Conflicts of interest: In compliance with the ICMJE uniform disclosure form, all authors declare the following: Payment/services info: All authors have declared that no financial support was received from any organization for the submitted work. Financial relationships: All authors have declared that they have no financial relationships at present or within the previous three years with any organizations that might have an interest in the submitted work. Other relationships: All authors have declared that there are no other relationships or activities that could appear to have influenced the submitted work.

\section{References}

1. Lamb CA, Kennedy NA, Raine T, et al.: British Society of Gastroenterology consensus guidelines on the management of inflammatory bowel disease in adults. Gut. 2019, 68:s1-s106. 10.1136/gutjnl-2019-318484

2. Zakko SF, Gordon GL, Murthy U, et al.: Once-daily mesalamine granules for maintaining remission of ulcerative colitis: pooled analysis of efficacy, safety, and prognostic factors. Postgrad Med. 2016, 128:27381. 10.1080/00325481.2016.1152876 
3. Brown G: 5-aminosalicylic acid-associated myocarditis and pericarditis: a narrative review . Can J Hosp Pharm. 2016, 69:466-72.

4. Caprilli R, Cesarini M, Angelucci E, Frieri G: The long journey of salicylates in ulcerative colitis: the past and the future. J Crohns Colitis. 2009, 3:149-56. 10.1016/j.crohns.2009.05.001

5. Caforio AL, Pankuweit S, Arbustini E, et al.: Current state of knowledge on aetiology, diagnosis, management, and therapy of myocarditis: a position statement of the European Society of Cardiology Working Group on Myocardial and Pericardial Diseases. Eur Heart J. 2013, 34:2636-48, 2648a-2648d. 10.1093/eurheartj/eht210

6. Dominguez F, Kühl U, Pieske B, Garcia-Pavia P, Tschöpe C: Update on myocarditis and inflammatory cardiomyopathy: reemergence of endomyocardial biopsy. Rev Esp Cardiol (Engl Ed). 2016, 69:178-87. 10.1016/j.rec.2015.10.015

7. Mitchell NE, Harrison N, Junga Z, Singla M: Heart under attack: cardiac manifestations of inflammatory bowel disease. Inflamm Bowel Dis. 2018, 24:2322-6. 10.1093/ibd/izy157

8. Braga CG, Martins J, Arantes C, et al.: Mesalamine-induced myocarditis following diagnosis of Crohn's disease: a case report. Rev Port Cardiol (English Edition). 2013, 32:717-20. 10.1016/j.repce.2012.12.005

9. Ibrahim A, Khalil C, Megaly M, Tawadros M, Mosleh W, Corbelli J: Mesalamine-induced myocarditis in a young athlete: can he run again?. Cureus. 2019, 11:e3978. 10.7759/cureus.3978

10. Baker WL, Saulsberry WJ, Elliott K, Parker MW: Cardiac MRI-confirmed mesalamine-induced myocarditis . BMJ Case Rep. 2015, 2015:bcr2015210689. 10.1136/bcr-2015-210689

11. Okoro KU, Roby MD, Bankole AA: Myocarditis secondary to Mesalamine-Induced cardiotoxicity in a patient with ulcerative colitis. Case Rep Med. 2018, 2018:9813893. 10.1155/2018/9813893

12. Taha ME, Abdalla A, Al-Khafaji J, Malik S: Mesalamine-induced myopericarditis: a case report and literature review. Cardiol Res. 2019, 10:59-62. 10.14740/cr820

13. Radhakrishnan ST, Mohanaruban A, Hoque S: Mesalazine-induced myocarditis: a case report. J Med Case Rep. 2018, 12:44. 10.1186/s13256-017-1557-z

14. Sorleto M, Dürrwald S, Wiemer M: Mesalazine-induced myopericarditis in a patient with a recent diagnosis of Crohn's disease: apropos of a case. Case Rep Cardiol. 2015, 2015:728310. 10.1155/2015/728310

15. Kingston T, Adham K, Harb R, et al.: Mesalamine Inducing Myocarditis: An Atypical Complication . Am J Gastroenterol. 2016, 111:S817.

16. Mellor T, Junga Z, Aduli: A rare complication of 5-ASA therapy . Am J Gastroenterol. 2012, 112:S1108. 